\title{
Looking for sources of human rights in Japanese traditions
}

\author{
Raji C. Steineck
}

What to look at, and what to look for in discussing sources of human rights in Japanese traditions

The notion of "human rights", especially if named "universal human rights" as in the pertinent UN declaration ("The Universal Declaration of Human Rights" 2013 (henceforth cited as UDHR), contains something of a paradox: If we accept their universality, we are wont to assume that they have been conceived, or at least have been conceivable, in all human societies at all times. But that would mean to obscure the historical truth (- and, lest we forget, truth is another "universal value" -) that, "universal human rights" were a revolutionary idea first legally adopted in nations fighting the European, colonialist ancien régime in the wake of the modern industrial age, most notably, because without the colonialist reservations that persisted in the case of revolutionary France, in the constitution of Haiti of 1804. Although they were soon adopted by progressives in the metropolis and, when the news spread, in the periphery of the colonialist / imperialist world, the idea in its popular understanding remained partial for some time (excluding women and the peoples and races destined, by the powers that be, for slavery or other forms of permanent subordination), and continued to meet with resistance around the globe. However, since it was ultimately successful, and has, since 1945, increasingly become a part of the global legal and quasi-legal framework, some former opponents (most notably, European conservatives and the Christian churches) have turned around and claimed, for their traditions, not only compatibility with the concept, but even intellectual responsibility for it.

If this be cunning, there is still reason in it, which makes such claims hard to reject. If we truly believe that human rights are unalienable and universal, we can hardly even want to think that they are at the same time fundamentally incompatible with convictions deeply engrained in anybody's cultural traditions. Moreover, as the 1990s' debate on human rights in Asia has shown, whenever human rights are "othered" as foreign impositions by apologists of some particularistic social ethics, we see local partisans come to the fore, claiming that those human rights are part and parcel of the best of the very tradition that is used to deny them (Cmiel 2004, 117). And this, or so I believe, is just as well. While I take human rights to be, both historically and in their very essence, a revolutionary idea - an idea that was and is most useful when directed against a status quo of systematic and cruel oppression of individuals and groups - there is good reason to argue that they express values which, at some level, have been present (albeit dormant, and possibly on the margins) in the relevant traditions of each country and society. If one were to shun that strategy, one would be left with a rhetoric of radical innovation, forcing people to choose between a presumed moral high ground (human rights) and the ways of life and thought they have followed so far. That, however, is for 
most people an impossible choice to make, the imposition of which can only generate anxiety and alienation. Conversely, to insist on specific and exclusive cultural roots for human rights in the traditions of the "Christian Occident", as a coalition of liberal cultural relativists and Euro-American conservatives would have it, does mean to deny to anybody who is identified, on their own accord or by someone else, as coming from another background the possibility to make the concept of human rights their own. This would also mean to consciously or inadvertently sound a note of Western suprematism, which can only alienate people in areas that were exposed to Western cultural and political imperialism. What follows from this is that, in order to avoid a self-defeating method in advancing human rights, we have to search for ways to picture them as standing in continuity with cultural traditions around the globe, without necessarily having to postulate that they were explicitly acknowledged in all areas, and at all times. In this manner, looking into historical sources can also help us to become aware of the relativity of each specific formulation of human rights to the social conditions of the age. It is worth noting that this strategy of establishing a continuity without insisting on identity was advanced in Japan already in the early decades of modernization by liberals such as Nishi Amane ${ }^{1}$ (Steineck 2013) or (in a less reflective manner) Yamaji Aizan (Squires 2001) against nationalist authoritarians such as Yamagata Aritomo, Shinagawa Yajirō, or Inoue Tetsujirō (Ito 2010).

It is with these preliminary thoughts in mind that I want to look, in the following pages, for possible intellectual sources of the concept of human rights in the premodern intellectual heritage of Japan. In my search, I shall consciously employ the same "hermeneutics of good will" that has traditionally been granted to slaveholders (Plato and Aristotle), profiteers of human trafficking (Locke; discussed in Glausser 1990), or racists (Kant; discussed e.g. in Bernasconi 2008, but see also Kleingeld 2007, who argues that he eventually changed his mind) when rooting human rights in the European traditions. I shall to some extend follow the pattern established by Micheline Ishay in her seminal The History of Human Rights (2008) in looking for both implicit and explicit acknowledgements of norms pertaining to liberty (namely, injunctions for tolerance, and restrictions of state interference in private affairs), equality (provisions for legal and social justice and universal welfare), and fraternity (willingness to extend respect and welfare to all human beings, regardless of social divisions). I will, however, not follow her in highlighting some ancient sources before jumping to the modern history of human rights. Instead, I will quite selectively mention some sources from antiquity and the medieval period, before discussing a particular early modern (Edo period), Confucian school of thought and its (partly diverging) ideas on human nature in more detail. This is not to privilege Confucianism as the single source relevant in

Japanese names are given in the customary Japanese order (family name first, personal name second). As for the references given, apart from primary sources directly discussed here, I have privileged sources in Western language over the vast and insightful pertinent scholarship in Japanese language simply for reasons of accessibility for the presumed readership of this volume. All translations from the Japanese are mine if not stated otherwise. 
establishing pre-cursors to the idea of human rights in Japan. Rather, I want to focus on the said $17^{\text {th }}$ century school of thought for two reasons: First, Confucian "role ethics" have been presented as contrasting, if not contradicting "European universalism" in parts of the literature, while others have argued quite to the contrary, that Confucianism is a token of "post-conventionalist", universalist ethics (most notably Roetz 1993). The controversy usually revolves around the "classical Confucianism", i.e. sources from Chinese antiquity. However one reads these sources, taking up early modern Japanese positions allows us to see something more of the diversity of opinions that developed within Confucianism, which in itself helps to foster a nuanced appreciation of the universalist and the conventionalist/particularistic tendencies and potentials in this tradition. As suggested above, in my view the problem is not so much whether ancient to early modern Confucianism (or Buddhism, or Shinto, for that matter) conceived of "human rights" in the way we do today. They did not, and could not, for Confucius, or Itō Jinsai, could no more than Plato or Aristotle have thought "equality" the way we do, nor of a "right to nationality" (UDHR, Art. 15) or a "right to work" (UDHR, Art. 23), which make sense in the modern system of nation states and capitalist economy only. The question, then, is whether a formulation and legitimation of human rights can be developed in Confucian etc. terms.

Looking at one later formulation of Confucian thought will also allow us to grasp, at least in part, the historical and dynamic character of this tradition, in contrast to the singular focus on its earliest and classical sources, which (albeit often inadvertently) serves to strengthen the conviction that there was no history of thought, no development of ideas, and thus, no progress, outside Europe.

\section{Elements of human rights in ancient and medieval Japan}

In the following, I want to turn the light on some important sources and developments in ancient and medieval Japanese history that can be read as documenting insights fundamental to the idea of human rights. For various reasons, the first text to turn to is the so-called "Seventeen Article Constitution" (in fact, more a collection of principles of government and administration then a fundamental law), documented in the Nihon shoki (fasc. 22), the first official history of the Japanese Kingdom, and attributed there to the Prince Regent Shōtoku (574?-622?), a figure in which retrospective imagination and historical facts are decidedly mixed (Como 2008, 4-5). Whatever the true origin of this document and the factual character of its putative author, both have time and again served as points of departure for discourses on what Japan is or should be like (Como 2008; Itō 1998), and in this vein the text has also recently been used as the corner stone for the largest collection of source-texts in Japanese Philosophy to date. (Heisig 2011, 35-39)

While the text as a whole evidently bears witness to the Yamato dynasty's effort to centralize government and install itself as the one and only source of authority (which in itself was - very benevolently - interpreted by the above-mentioned Yamaji Aizan as an attempt to protect the common people "from the despotism of the nobility" (Squires 
2001, 152; cf. Yamaji 1965, 315), several of its articles are of relevance to our search for sources of human rights in the Japanese traditions. Yamaji (ibd.) specifically takes up article 12, which bars provincial officials and nobility from exacting levies, as evidence of the intention to protect the welfare of the common people:

Neither Provincial governors nor the provincial nobility shall collect levies or impose labour on the good people. The country does not have two lords, and the people do not have two masters. The king is the master of all people in the land. The officials he entrusts are all his vassals. How can they, aside from the government, collect levies from the common people? (NST 2, 18; 19; compare the modernizing translation in Heisig 2011,38)

If this is about protecting the "good people" (J. hyakusei 百姓, also read ohomutakara, lit. "the (king's) treasure", which may be understood quite literally as those who contribute to the royal treasury by tax and corvée labor, as distinguished from the itinerant and lowly, tax evading senmin 賤民), it is at least as much about establishing a royal tax monopoly, and a principle of suzerainty hitherto unknown in Japan.

Less ambiguous are the articles 5, 6,10 and 11, which relate to values such as impartiality, tolerance, and justice, and explicitly mean to protect the weak from extortions by the rich and powerful, including corrupt officials. Article 5 reads:

Stop craving for delicacies, give up greed, and decide petitions in a transparent manner. ... Recently, those deciding over petitions take profit as their constant, and hear cases with a view to bribes. Thus the petitions of the wealthy pass like stones being thrown into the water. Those of the poor resemble water being thrown at a stone. If things are like this, poor commoners have nowhere to turn to. Consequently, the way of the vassal-ministers is compromised. (NST 2, 14; 15); cf. again Heisig 2011, 37)

While there is no idea of a "right" of the common subjects to receive equal treatment, the principle of impartiality in itself is evidently, and explicitly, formulated - a principle that, under the conditions of the rule of law, may well be transposed into the idea that "All are equal before the law and are entitled without any discrimination to equal protection of the law." (UDHR, Art. 7)

Our text's Article 10 calls for tolerance with respect to diverging opinions. This may well have first and foremost referred to policy discussions among the governing elite, but the injunction is put forth in a general way:

Stop being wrathful, discard rage, and don't be angered by people who differ. Everyone has a mind, and something his heart clings to. What they think is good may be bad for us. What we think is good may be bad in their eyes. We are not necessarily sages, nor are they necessarily stupid. After all, we all are just ordinary, deluded people (J. bonpu 凡夫). Who can decide what is good or bad? We all alternate between wisdom and stupidity, without end, like a ring. Thus, even if the other side is enraged, we should be worried lest we ourselves are mistaken. Even if we think we alone have grasped the matter, we should submit to consensus. (NST 2, 18; 19)

While the last sentence may read like a license to opportunism, it is generally understood as an injunction against the magisterial enforcing of judgements on a reluctant 
majority. (NST 2, 383) The passage may thus be understood as putting forth the principle of tolerance not only of divergent views, but also of different ways of life, as a principle of governance - a principle translatable into the granting of civil liberties, such as granted by the UDHR's Art. 12.

One could also find at least the first traces of an idea of human equality here in the absence of reference to privileged insights of the ruler. But no mention is made (as yet) of a human intelligent or moral nature that would substantiate claims for human dignity - instead, the text refers to the limitations of human capacities in arguing against the arrogance of those in positions of power.

Articles 6 and 11 of "Shotoku's Constitution" request rulers to "punish wickedness and encourage goodness", and to honor merit appropriately. Since Article 6 precedes article 10, it also restricts its apparent relativism, implying the indisputability of certain moral standards. Again, this is not articulated in terms of formal law and legal justice, but Article 6 makes explicit reference to a "golden rule of antiquity" (Heisig 2011, 37; NST 2,$14 ; 15)$, which makes it open to a reading conformant to principles of equality before the law, impartiality of justice, and the like.

The political and legal thinking of these injunctions is largely informed by the Chinese classics that, in the West, have been subsumed under the term "Confucianism", with notable elements of Buddhist thought (as apparent in the term "ordinary, deluded people" in Art. 10). The latter is also deemed mainly responsible for the remarkable discontinuation of capital punishment in later antiquity subsequent to a decree issued by Saga Tennō in 818 that "all capital punishment for theft be mitigated into incarceration," which lasted until militant political conflict resurfaced in the capital with the Hōgen disturbance of 1156 (Schmidt 2002, 11; see ibd. 11-12 for an overview of the explanations given in the pertinent literature).

In the ensuing medieval period, marked by the preponderance of armed conflict and a military aristocracy, penal law and practice reverted to increasingly violent means, and capital punishment was frequently applied even for minor offenses (Schmidt 2002, 12-15). On the other hand, new concepts conducive to a universalist understanding of human nature and dignity were developed within the dominant religious paradigm that combined the cult of local and national deities with Buddhist creeds and practices. In the field of Buddhist doctrine, the resurgence of armed conflict and the increasing social violence resonated with the notion of a "final age of the Dharma” (mappō 末法) in which human beings would be increasingly dependent on the grace of Buddhas and Bodhisattvas for salvation. While the widely popular concept of reliance on the "other power" (tariki 他力) of Buddha Amida was arguably designed to work against spiritual elitism and arrogance (see the statements by Hōnen and Shinran, quoted in (Heisig 2011, 247-248; 253-255), it did translate into tendencies for social egalitarianism, including the establishment of a regional non-aristocratic selfgovernment in one area of Japan that lasted for over 100 years (Pauly 1985). Conversely, other schools of Buddhism emphasized the idea of a "Buddha nature" (busshō 仏性) shared by all living beings and of an "original enlightenment" (hongaku 本覚) inherent to human nature to counter the notion that some human beings were born 
without the moral and spiritual capacity for enlightenment. (Both terms were interpreted in various ways; see Stone (1999) for a window into this discourse.) These concepts were, with notable contributions by Buddhist monks, translated into a fledgling Shinto theology (Teeuwen 1998; Fabio Rambelli 2009). The Ruijü jingi hongen 類聚神祇本源 (“The Original Source of the Classified Texts pertaining to the Heavenly and Earthly Deities"), a fascinating text that attempts a Shintō synthesis of the Chinese classics, Buddhist sources, and Japanese Mythology, has in its chapter on "The Deeper Meaning of the Way of the Gods" an early formulation of a thought that is, to say the least, open to readings supportive of a positive notion of human dignity: "Man is the divine / sacred being on earth." (Hito wa sunawachi tenka no shinbutsu nari 人八刀チ天下ノ神物也。NST 19,115) While modern Shintoists have generally more excelled in championing Japanese particularism, if not chauvinism (Antoni 1998), this serves to show that there is no need to exclude this tradition when connecting the idea of human rights to older Japanese sources.

\section{Discourses on Humaneness and Human Nature in Early Modern Japan}

From these perfunctory glosses into Buddhist and Shintō sources from late antiquity and the medieval period, I turn to the literature generally categorized as "Old Learning" (J. Kogaku 古学). Kogaku, which as a historical label refers more to a methodological paradigm of giving prevalence to "old" (Zhou to Han period) over "new" (Song and Ming period) sources than to a unified school of thought, emerged in the $17^{\text {th }}$ century from critical reflections on the then dominant school of Chinese Learning that based itself on the metaphysics of Chinese Song-period thinkers such Zhou Dunyi (1017-1073) and Zhu Xi (1130-1200.

With the firm regulation of religion in general and Buddhist institutions in particular enacted by the Tokugawa Shogunate, the language of Classical Chinese scholarship (which is a more appropriate circumscription of what in the West is popularly called "Confucianism") within a few decades became the dominant idiom of intellectual discourse, supplying paradigms which in turn inspired new forms of Buddhist scholarship and a national learning movement that was seminal for the development of a modern nationalist ideology.

The government-sponsored Hayashi School (founded by Hayashi Razan 林羅山, 1583-1657) emphasized a grand, but ultimately static view of the natural and social cosmic order (Brüll 1970; Boot 1979; Brüll 1989) that resonated well with the shogunate's efforts to stabilize the realm and its own grip on power (Totman 2000, 219225). In terms of individual moral practice, this school, in line with the inspiration it drew from Buddhist sources and practices, emphasized "quiet sitting" (seiza 静坐) as a means of reverting to one's original nature inherently in tune with cosmic principle (Tucker 2004, but see Tucker 2002 for an interesting exception to the rule).

In contrast, the "Old Learning" paradigm, represented by thinkers with no (or severed) ties to the shogunate, and partly a townspeople rather than an aristocratic background, preferred a more dynamic reading of human nature that foregrounded moral 
and political action. In the following, I turn to two representative thinkers of this tradition, Itō Jinsai 伊藤仁斎 (1627- 1705) and Ogyū Sorai (1666-1728), not least because the latter inspired the great Meiji period philosopher Nishi Amane 西周 $(1829-1897)$ to conceive of a modern and liberal variant of Confucian philosophy (Steineck 2013).

Itō Jinsai's Gomō jigi 語孟字義 (Meanings of terms in the Lunyu and Mengzi) discusses seminal terms of Confucius' Analects and Mencius with a critical, sometimes polemical view to their interpretation in the tradition of Song and Ming scholars. Chapter eight is dedicated to "human nature" (sei). In its second paragraph, Jinsai refutes the notion of an "original state of human nature" (honzen no sei 本然の性) that would be characterized by an apriori form of goodness, regardless of an individual's empirical capacity for, and record of, moral action (Tucker 1998, 134-135; NST 33, 48-50). Jinsai, who identifies human nature with the inborn disposition, declines the idea of a kind of inherently good spiritual nature that would be the same in all human beings. To the contrary, he believes that humans are born with different dispositions, but that they all share a moral sense that sets them apart from animals. This implies two things: being able to discern good from bad, and a natural preference for what is good that may, however, loose out to other impulses according to individual disposition and habitus (i.e., degree of moral cultivation). This is how he interprets Mencius' concept of the goodness of human nature:

Mencius also explained, "People can become good because of their feelings (jo 情). That is what I mean in saying human nature is morally good." Mencius' point was that chickens and dogs, lacking any ethical understanding, cannot be taught goodness. But human feelings are such that, despite the reality of extremely inhumane deeds such as theft and murder, people are happy when praised and upset when chastised. In knowing the good to be good and the bad to be bad, both are the ground for the doing of good. That is what we mean by saying that human nature is good, and not that everyone's nature on earth is the same and we don't find anyone who is bad. From this it is clearly evident that Mencius' saying about human nature being good is not at variance with Confucius' saying that humans are similar in nature (NST 33, 50; the translation of the first three sentences is taken from Tucker 1998, 135).

The ensuing paragraphs of his discussion of human nature make it even more clear that Jinsai identifies the specific and indelible trait of human nature that distinguishes humanity from other animals not as a substantial goodness, but as the ability to know good from bad, which is, as he goes on to say, is the foundation for all moral as well as immoral acts; in paragraph 4 he writes:

All talk of the good is in contradistinction to what is bad. When there is the good, there is also the bad. But if we, by conjecture, attempt to grasp their ultimate origin, we will inevitably end up relying on goodness (NST 33, 52, cf. Tucker 1998, 138).

Two points are of special importance in the context of our discussion. Firstly, we have a clear formulation of the moral nature of human beings that can serve as a conceptual foundation for the articulation of human dignity (Art. 1, UDHR) and might, via its implicit reference to human freedom, be developed into a Confucian articulation of civil liberties. And secondly this moral nature is conceptually removed from questions 
of moral substance or merit: even "thieves and thugs who commit horrible crimes" (Tucker 1998, 139; cf. NST 33, 52) in Jinsai's eyes are not exempt from partaking in it. In thus clearly distancing the notion of human moral nature from questions of merit or demerit, Jinsai not only explicitly emphasizes the possibility and importance of moral cultivation (which connects to the right to education and participation in social life). His concept also speaks against acts that deny to humans the status of moral agents, regardless of the origin, status, and moral record of the person in question.

It is, in this respect, interesting to see how Jinsai deals with the traditional distinction between the noble few and the common crowd (kunshi shöjin 君子小人; chapter 23). First, he points to the history of the terms, which initially indicated status distinctions, but later came to refer to differences in record and were, as Jinsai says, polemically used in cases where there was a positive or negative mismatch between merit and social status. He then goes on to further identify "the way of the refined / noble person" (kunshi no michi 君子の道) from the “way of the sage” (seijin no michi 聖人の道): while the latter is only accessible for people of exceptional capacity, the former is open to all and characterized by its unobtrusiveness. Jinsai, who hailed from a non-aristocratic background, seems to consciously emphasize the constant, even pedestrian nature of the "way of the noble person" in an effort to subvert the social and political elitism traditionally connected with the above named distinction (NST 33, 80-81; Tucker 1998, 195-197).

Ogyū Sorai 荻生徂徠 (1666-1728), a member of the warrior class and for a period of time counselor to Shogun Tsunayoshi's chief advisor Yanagisawa Yoshiyasu (Lidin 1973, 38-51), is certainly less of a candidate than Jinsai if one were to search for precursors of democratic values in premodern Japan. However, his criticism of the tendency of the tradition to conflate the virtues of good government with general thoughts on human nature and the cultivation of benevolent feelings may be seen as laying the groundwork for the separation of the spheres of law and morality, and thus, for a theory of a state of law. This was, incidentally, the way in which the $19^{\text {th }}$ century liberal philosopher Nishi Amane read and developed his ideas (see below). Furthermore, Sorai continues Jinsai's championing of moral action in contrast to the emphasis on "returning to the source" and "quiet sitting" (although he criticizes Jinsai rather severely on other points, see e.g. Tucker 2006, 189).

In chapter three of his own work on terminology, Benmei ("Discussion of terms"), Sorai defines the central virtue of "humaneness" (C. ren, J. jin 仁) as "the virtue of being a leader of men and providing for the peace and stability of the common people." (NST 36, 53; Tucker 2006, 186 omits the part about leadership.) To his understanding, it is thus clearly a virtue of the governing elite, and not for commoners. He goes on to criticize the received view:

Confucians of later generations did not fathom the way of the sages, and so misunderstood humaneness. They claimed, "Humaneness is the principle of live and the virtue of the mind." They further alleged, "Humaneness appears when selfish desires are fully cleansed and the principles of heaven flow actively." ... Their insights on humaneness derived from the teachings of Buddhism and Daoism. Consequently, they emphasized 
notions such as "principle" and "the mind." Because later Confucians misread the Doctrine of the Mean and Mencius, they interpreted humaneness as human nature. ... Their idea was that the humane person loves humanity. However, love is simply a feeling. If the feelings are quieted, as they advocated, how could love become manifest?" (Tucker 2006, 188; cf. NST 36, 55)

It is, by the way, clear for Sorai that, while "humanity" consists in the enactment of practical policies for the sake of the whole population, the moral cultivation of those assuming governmental authority remains an essential element:

Practicing humane government takes self-cultivation as its foundation. If selfcultivation is not engaged in, the people will not follow even if humane government is enacted (Tucker 2006, 191; cf. NST 36, 57).

Taking this as an aside as to the importance of moral credibility in politics that one would certainly wish contemporary politicians to take to heart, I want to focus here on Sorai's emphasis on governing in a way that is practically beneficial - and not just abstractly benevolent - to all in favoring "creative production" (as Tucker aptly translates sei 生 in this context; Tucker 2006, 186; NST 36, 53) and fostering social cooperation while taking account of the divergences in individual dispositions.

Sorai highlights providing for a peaceful and stable social environment and creating a social structure in which everyone can prosper by contributing to social live according to their talent as the two central embodiments of "humaneness" (NST 36, 5354; Tucker 2006, 186-187). Sorai specifically insists that precisely because humans differ in their individual dispositions, they can be, and need to be, integrated into a society where their capacities are made to work for mutual benefit - and it is the responsibility of those with governmental authority to provide for such a framework:

While human nature does differ from person to person, regardless of an individual's knowledge or ignorance, worthiness or worthlessness, all are the same in having minds that mutually love, nourish, assist, and perfect one another. People are also alike in their capacity to work together and undertake tasks cooperatively. Thus for government, we depend on a ruler; for nourishment, we depend on the people. Farmers, artisans, and merchants all make a living for themselves by relying upon each other. One cannot forsake society and live alone in a deserted land: it is simply human nature that makes it so. Now, "the ruler is one who organizes people into groups." Were it not for the virtue, humaneness, how could people possibly be so well organized and unified into society? (Tucker 2006, 187; cf. NST 36, 54)

Sorai also affirms the old Chinese idea that this is what in the long run legitimizes governmental authority (NST 36, 57; Tucker 2006, 190). In stressing the importance of concretely beneficial policies over against the quietistic contemplation of lofty ideals, he is certainly closer to a "materialist" reading of human rights. He may thus be read with an eye towards to rights for securing individual survival, participation in social and cultural life, and, to some extent, distributive justice (UDHR, Art. 1, 2, 22).

To reiterate, by highlighting these thoughts of Sorai, I do not want to imply that he or any other source previously quoted here had a theory of human rights in mind. I 
simply want to indicate that the idea of human rights and some of its more concrete articulations do resonate well with seminal concepts from various older Japanese traditions. In other words, I want to suggest that Japanese is a possible "native language" of human rights - that human rights can be formulated by making use of traditional terminology and with reference to time-honoured ideas from what has been received as the canon of Japanese thought. This will, however, not be possible if one subscribes to a form of traditionalism that accepts these sources as authorities that reign supreme. Instead, one has to opt for a kind of creative reading of the tradition that allows for their re-interpretation and adaptation in the light of new insights and circumstances. As I have mentioned already in the introductory paragraph, such a reading is not without precedent in Japanese modernity: It was already employed in the early decades of political modernization by various liberal intellectuals in their struggle against the nativist authoritarianism that ultimately carried the day - eventually leading up to the cataclysms of Japanese imperialist chauvinism, and the breakdown of the empire in 1945. Since we are currently witnessing a resurgence of nationalist ideologies in Japan, this alternative, and its continuity to what may arguably be the best of the intellectual tradition of Japan, surely deserves renewed attention.

I therefore want to close this paper by very briefly highlighting how Nishi Amane, often termed "the father of [scil. modern] Japanese philosophy" (Botz-Bornstein 2006, 70), attempted to critically develop a "Confucian" theory of the rule of law, and civil liberties. While Nishi is today mainly "known for his pioneering work in introducing European philosophy and other disciplines into Japan" (Heisig 2011, 583), and most notably for coining the term tetsugaku 哲学, which has come to denote philosophy in the Western tradition, he also strove to connect what he had learned in Europe to the tradition he had first studied - Classical studies in the tradition of Ogyū Sorai. This is most obvious in his "New theory of the unity of the various fields of learning" (Hyakuichi shinron 百一新論, 1874; NAZ 1, 232-289). Consider the following paragraph, which reads like a modernized version of Sorai:

Some scholars suppose that by coming to know the 'principle' of all things and to have a sincere heart and 'mind' they can spontaneously govern the country without further study; without investigating and clarifying what is in its interests or to its advantage. It is painful to think of the harm that would result from governance based on something like a Zen monk doing 'zazen'. (Heisig 2011, 584; NAZ 1, 237-238)

Witness also the following reflections from a later treatise:

... Human society, too, comes about because of the benefits it brings: the morality of mutual support (as with husband and wife, or father and son), the laws of division of labor (the exchange and distribution of work), the distinction between leaders and commoners (those in office and those not in office) and between government and citizens (the judiciary prevents conflicts, the army protects the nation). Hence, seeking what is beneficial is the basis of morality. The way of freedom does not gainsay the pursuit of gain. (Heisig 2011, 584; cf. NAZ 2, 312) 
One immediately notices the similarities to the paragraph from Sorai quoted above, but also how the old ideas are transposed into a new key, which is adapted to modern circumstances and based on a notion entirely absent in Sorai (or any of the other sources quoted above), i.e. that of “freedom" (J. jiyu 自由). (The treatise bears the title: "On the Idea that Freedom is Independence.") Nishi converts the old idea that maintenance of authority is dependent on the ability to exert it for the benefit of all into the modern concept that the establishment of the state limits individual discretion for the sake of general freedom. However, he ingeniously connects traditional "Confucian" notions to modern liberalism by defining freedom through its relation to benefit: "Freedom is the freedom to attain what is beneficial (jiy $\bar{u}$ wa iwayuru shūri no jiy $\bar{u}$ nari 自由者所謂就利之自由也)”, and thus connects Sorai's notions of social cooperation, beneficial government and dutiful behavior to the golden rule of the modern liberal state:

Those who are loose with the limits [of freedom] cannot but be treated strictly, and therefore we cannot use our own freedom to violate the freedom of fellow human beings. ... Only animals, insects, fish and the like are free to pursue and gain benefit for themselves alone. In human society, one forfeits this smaller, lower form of freedom to obtain a greater, higher freedom. (NAZ 2, 312; the English translation of the last two sentences taken from Heisig 2011, 584-585)

One of the central points of Hyakuichi shinron that is pertinent to our discussion of human rights is Nishi's critique of the tradition for its neglect to distinguish the sphere of law properly from that of morality, and his subsequent introduction of the term "right" (J. ken 権) into the discourse (NAZ 240-247). Having argued that "law" (J. ho 法) and morality (J. kyo 教) differ both in intension and extension (NAZ 1, 263-265), Nishi goes on to reassure his readers that "law has its origin in human nature" (J. ho wa motomoto hito no sei ni motozuku mono 法は元人の性に基づくもの) and is therefore implicitly present in the (Chinese) classics as well, where it is, he says, subsumed under the term $g i$ 義 (“obligation”). Nishi explains:

What is called "obligation" emerges in the relation between two people. For example, the retainer has the "obligation" to serve his lord, and conversely, the lord has the "obligation" to support the retainer. With the respect to such obligations, there also emerges what is called a "right" (ken 権) - but in the Han Classics, this also was called "obligation," and the two were not clearly differentiated. In contrast, in Western thought both are separated, and consequently there is much talk of "rights" there. However, the idea of a "right" is present in the Analects when they speak of there being an "obligation" that one grasps later, or that one looks to an "obligation" with an eye to profit. In Mencius, it is discussed whether one would be righteous or unrighteous when taking such an "obligation" - and while this is also called an "obligation", it is said with respect to the side of the one who takes, and is different from the obligation to give something. This is what in the West is called a "right". For example, the retainer has a "right" to receive support from the lord. The lord has a "right" to expect obedience from the retainer. Thus, rights and duties spring forth mutually between two people. (NAZ 1, 272-273) 
We can see here how Nishi at once critiques the tradition and strives to maintain continuity with it. Through this creative form of reading he is able to introduce modern notions of liberties, the rule of law, and the like while maintaining the link to the cultural heritage. Nishi by the way anticipated that the introduction of a discourse of rights might be perceived as fomenting dissent and conflict in society, and that some would take recourse to the revisionist idea of replacing the discourse of "rights" entirely by the promotion of morality. But while he did believe that "rights" can only work properly and beneficially if complemented by "morality", an awareness of duties that complements the awareness of rights, he was adamant that regress to the confusion of the spheres of law and morality is not viable, and could only be to the detriment of both. (NAZ 1, 274)

\section{Conclusion}

I have shown in the preceding paragraphs that seminal documents from various pre-modern Japanese schools of thought provide for terms and concepts that can be used to articulate and legitimize the idea of human rights in a language that is in continuity with Japanese (and East Asian, for that matter) tradition. There is thus no need to invoke East-West dichotomies, or fear that by promoting human rights, one would of necessity impose "alien" ideas on Japanese society. My remarks are first and foremost addressed at a Western audience, and meant as a critical intervention with an eye to both a conservative "universalism" that assumes the concept of human dignity to be a Christian Occidental invention and prerogative, and a liberal "cultural relativism" that shies away from posing hard questions to "traditionalist" defenders of Asian variants of authoritarianism. However, I would also like to express the hope that Japanese philosophers and intellectuals re-discover and re-appropriate the strategies of Meiji liberals like Nishi Amane, and move confidently beyond the dichotomical paradigm that has, for the most part of the $20^{\text {th }}$ century, and certainly not for the better of Japanese society, forced Japanese to choose between authoritarian traditionalism and a liberal (or Marxist) universalism that spoke with a distinctly "Western" tongue.

An immediate qualification is in place: By demonstrating that it is possible to couch human rights issues in terms that invoke continuity to older Japanese traditions, I do not want to say that it is necessary for Japanese to do so. First of all, there is no duty to cater to national tradition, and one may have good reason to keep one's distance. Secondly, even if one chose, while arguing for human rights, to also participate in the work of imagining the national community, one might as well opt for highlighting one of the modern intellectual traditions of Japan (such as Kantianism or Neo-Marxism, for example). It is simply my point that the option exists to connect the idea of human rights to traditions pre-dating the influence of Western thought, and thus present it in a genuinely "Japanese" light. Since we live in societies where individuals are to some extent defined by attributions of nationality, and large parts of the population identify themselves by belonging to a nation, this option seems important if one wants the idea of human rights to succeed. And, to re-iterate, the said proposition goes both ways: 
while it affirms the possibility to be a "good Japanese" and at the same time champion human rights issues, it negates an exclusive link of human rights to Occidental traditions. Human rights are a revolutionary idea - but one which can draw on sources from all parts of the world.

\section{References Cited}

Antoni, Klaus J. 1998. Shintō und die Konzeption des japanischen Nationalwesens (kokutai): der religiöse Traditionalismus in Neuzeit und Moderne Japans. Handbook of Oriental studies 8. Leiden, Boston: Brill.

Bernasconi, Robert. 2008. "Kant as an Unfamiliar Source of Racism". In Philosophers on Race: Critical Essays, ed. Julie K. Ward and Tommy L. Lott, 145-165. Oxford et al.: Blackwell.

Boot, W. J. 1979. "Hayashi Razan as a Confucian Philosopher". In European studies on Japan, ed. Charles Dunn, 89-94. Tenterden: Norbury.

Botz-Bornstein, Thorsten. 2006. "Russian and Japanese Philosophies: A Comparative Study“. In Philosophical Frontiers: Essays and Emerging Thoughts, ed. Richard H. Corrigan and Mary E. Farrell, 69-90. Progressive Frontiers Press.

Brüll, Lydia. 1970. „Prinzip (ri) und Materie (ki). Ein Beitrag zur Metaphysik des Hayashi Razan“. In Japanisches Kulturinstitut Jahrbuch 1970, ed. Japanisches Kulturinstitut Köln, 5-31. Köln: Japanisches Kulturinstitut Köln.

- - - 1989. „Die Begriffe Weisheit, Menschlichkeit und Beherztheit bei Hayashi Razan“. In Bochumer Jahrbuch zur Ostasienforschung 13, 1-14.

Cmiel, Kenneth. 2004. "The Recent History of Human Rights“. The American Historical Review 109 (1) (Februar 1): 117-135.

Como, Michael. 2008. Shōtoku: ethnicity, ritual, and violence in the Japanese buddhist tradition. New York, New York: Oxford University Press.

Glausser, Wayne. 1990. "Three Approaches to Locke and the Slave Trade“. Journal of the History of Ideas 51 (2) (April 1): 199-216. doi:10.2307/2709512.

Heisig, James W. 2011. Japanese Philosophy: A Sourcebook. Univ of Hawaii Pr.

NST = Nihon shisō taikei. Tōkyō: Iwanami Shoten.

Vol. 2: Ienaga Saburō 家永三郎 (ed.). 1975. Shōtoku Taishi shū 聖徳太子集. Vol. 33: Yoshikawa, Kōjirō 吉川幸次郎 (ed.). 1971. Itō Jinsai; Itō Tōgai 伊藤仁齋 ； 伊藤東涯.

Vol. 36: Yoshikawa Kōjirō 吉川幸次郎 et al (ed.). 1973. Ogyū Sorai 荻生徂徠.

Ishay, Micheline R. 2008. The History of Human Rights: From Ancient Times to the Globalization Era. University of California Press.

Itō, Kimio. 1998. "The Invention of Wa and the Transformation of the Image of Prince Shôtoku in Modern Japan“. In Mirror of modernity: invented traditions of modern Japan, Hrsg. Stephen Vlastos, 37-47. Berkeley: University of California Press.

Ito, Yushi. 2010. "Conflicting views of Japan's mission in the world and national moral education: Yamaji Aizan and his opponent Inoue Tetsujirō". Japan Forum 22 (3-4): 307-330. doi:10.1080/09555803.2010.531554.

Kleingeld, Pauline. 2007. "Kant's Second Thoughts on Race“. The Philosophical Quarterly 57 (229): 573-592. doi:10.1111/j.1467-9213.2007.498.x. 
Lidin, Olof G. 1973. The life of Ogyū Sorai, a Tokugawa Confucian philosopher. Lund: Studentlitteratur.

NAZ = Nishi Amane Zenshū. Nishi, Amane 西周. 1981. Nishi Amane Zenshū 西周全集. Reprint. Tōkyō: Munetaka Shobō.

Pauly, Karl Ulrich Wolfgang. 1985. Ikkō-Ikki: die Ikkō-Aufstände und ihre Entwicklung aus den Aufständen der bündischen Bauern und Provinzialen des japanischen Mittelalters. Bonn.

Rambelli, Fabio. 2009. "Before the First Buddha: Medieval Japanese Cosmogony and the Quest for the Primeval Kami“. Monumenta Nipponica 64 (2): 235-271.

Roetz, Heiner. 1993. Confucian Ethics of the Axial Age: A Reconstruction Under the Aspect of the Breakthrough Toward Postconventional Thinking. Albany: SUNY Press.

Schmidt, Petra. 2002. Capital Punishment in Japan. BRILL.

Squires, Graham. 2001. "Yamaji Aizan's Traces of the Development of Human Rights in Japanese History“. Monumenta Nipponica 56 (2) (Juli 1): 139-171. doi:10.2307/ 2668406.

Steineck, Raji C.. 2013. "Der Begriff der Philosophie und seine taxonomische Funktion bei Nishi Amane.” In Begriff und Bild der modernen japanischen Philosophie, ed. Raji C. Steineck, Paulus B. Kaufmann, Elena L. Lange. Stuttgart: Frommann-Holzboog 2013 (in press).

Stone, Jacqueline. 1999. Original enlightenment and the transformation of medieval Japanese Buddhism. Studies in East Asian Buddhism 12. Honolulu: University of Hawai'i Press.

Teeuwen, Mark. 1998. Nakatomi harae kunge purification and enlightenment in late-Heian Japan. Buddhismus-Studien 1. München: Iudicium-Verlag.

„The Universal Declaration of Human Rights“. http://www.un.org/en/documents/udhr/. Last access: Jan 16, 2013.

Totman, Conrad, Hrsg. 2000. A History of Japan. Malden, Mass: Blackwell.

Tucker, John Allen. 1998. Itō Jinsai's Gomō jigi and the philosophical definition of early modern Japan. Brill's Japanese studies library Vol. 7. Leiden etc.: Brill.

- - . 2002. "Quiet-Sitting and Political Activism: The Thought and Practice of Satō Naokata“. Japanese Journal of Religious Studies 29 (1/2) (April 1): 107-146. doi: $10.2307 / 30233703$.

- - - 2004. "Art, the Ethical Self, and Political Eremitism: Fujiwara Seika's Essay on Landscape Painting“. Journal of Chinese Philosophy 31 (1): 47-63. Ordner „Konfuzianismus“. doi:10.1111/j.1540-6253.2004.00142.x.

- - - 2006. Ogyū Sorai’s Philosophical Masterworks: the Bendō and Benmei. Honolulu: University of Hawai'i Press.

Yamaji Aizan 山路愛山. 1965. Yamaji Aizan shū 山路愛山集. Meiji bungaku zenshū 35. Tōkyō: Chikuma Shobō. 